East European Journal of Physics

East Eur. J. Phys. Vol.5 No.3 (2018) 61-67

DOI: $10.26565 / 2312-4334-2018-3-07$

PACS: $81.65 . P s$

\title{
ELECTROLYTIC PLASMA POLISHING OF COPPER
}

\author{
O.V. Mihal, O.V. Moroz, R.I. Starovoytov, I.V. Buriak \\ V. N. Karazin Kharkiv National University \\ Svobody Sq. 4, 61022, Kharkiv, Ukraine \\ E-mail:oleksii.mihal@gmail.com, https://orcid.org/0000-0002-3512-6477 \\ Received July 12, 2018; revised August 28, 2018; accepted September 6, 2018
}

\begin{abstract}
Modern industrial technological processes require special preparation of metal surfaces. Currently, there are different methods of surface treatment of metal. Among them, it is possible to distinguish the method of electrolytic-plasma polishing (PEP- plasma electrolytic polishing) is distinguished as an innovative, due to its ecological properties, low energy consumption per unit of surface to be processed, high speed of modification and the possibility of processing parts of complex geometric shape. The main advantage of this method of surface modification is its ecological purity, which makes it possible to apply this technology to the food and pharmaceutical industry. Despite the large number of journal publications, electrolytic plasma polishing remains an innovative surface modification method that needs to be thoroughly studied in order to improve understanding of physical processes and optimize the surface modification process. The process of obtaining electrolytic plasma polishing of copper products in a solution of ammonium sulfate with the addition of sulfuric acid is considered in the paper. The experiment was divided into two stages. At first, the samples were treated for 600 seconds each for the obtain of temperature characteristics, with a strong correlation between the load current and the electrolyte temperature was observed. Dependence of the current on the temperature of the electrolyte showed four different modes of treatment. One of the modes showed the best results. During the second series of experiments, the processing of objects from 30 to 600 seconds. As a result of the conducted studies, optimal regimes for polishing copper objects were obtained.
\end{abstract} KEYWORDS: electrolytic-plasma polishing, metal working, surface relief; modification of the surface; temperature of electrolyte

\section{ЕЛЕКТРОЛІТНО-ПЛАЗМОВЕ ПОЛІРУВАННЯ МІДІ \\ О.В. Мігаль, О.В. Мороз, Р.І. Старовойтов, І.В. Буряк \\ Харківський наиіональний університет імені В.Н. Каразіна 61022, Харків, м. Свободи, 4}

Сучасні промислові технологічні процеси вимагають спеціальної підготовки металевих поверхонь. В даний час існують різні методи обробки поверхні металу. Серед них можна виділити метод електролітно-плазмового полірування (РЕР plasma electrolytic polishing), як інноваційний, завдяки своїм екологічним властивостям, низьким енергозатратами на одиницю оброблюваної поверхні, високою швидкістю модифікації та можливість обробки деталей складної геометричної форми. Основною перевагою даного методу модифікації поверхні є його екологічна чистота, що дозволяє застосовувати дану технологію для харчової та фармацевтичної промисловості. Незважаючи на велику кількість публікацій у журналах, електролітно-плазмове полірування залишається інноваційним методом модифікації поверхні, яку необхідно ретельно вивчати, щоб поліпшити розуміння фізичних процесів та оптимізувати процес модифікації поверхні. У даній статті розглянуто процес електролітно-плазмового полірування мідних виробів у розчині сульфату амонію 3 додаванням сірчаної кислоти. Експеримент був розділений на два етапи. Спочатку зразки оброблялися протягом 600 секунд кожен для зняття температурних характеристик, при цьому спостерігалася сильна кореляція між струмом навантаження і температурою електроліту. Залежність струму від температури електроліту показала чотири різні режими обробки. Один 3 режимів показав найкращі результати. Під час другого етапу експерименту проводилася послідовна обробка об'єктів від 30 до 600 секунд. У результаті проведених досліджень були отримані оптимальні режими полірування мідних об'єктів.

КЛЮЧОВІ СЛОВА: електролітно-плазмове полірування, металообробка, рельєф поверхні; модифікація поверхні; температура електроліту

\section{ЭЛЕКТРОЛИТНО-ПЛАЗМЕННАЯ ПОЛИРОВКА МЕДИ \\ А.В. Мигаль, О.В. Мороз, Р.И. Старовойтов, И.В. Буряк \\ Харьковский национальный университет имени В.Н. Каразина 61022, г. Харьков, пл. Свободы, 4}

Современные промышленные технологические процессы требуют специальной подготовки металлических поверхностей. В настоящее время существуют различные методы обработки поверхности металла. Среди них можно выделить метод электролитно-плазменной полировки (РЕР- plasma electrolytic polishing), как инновационный, благодаря своим экологическим свойствам, низким энергозатратам на единицу обрабатываемой поверхности, высокую скорость модификации и возможность обработки деталей сложной геометрической формы. Основным преимуществом данного метода модификации поверхности является его экологическая чистота, что позволяет применять данную технологию для пищевой и фармацевтической промышленности. Несмотря на большое количество публикаций в журналах, электролитноплазменной полировки остается инновационным методом модификации поверхности, которую необходимо тщательно изучать, чтобы улучшить понимание физических процессов и оптимизировать процесс модификации поверхности. В данной статье рассмотрен процесс электролитно-плазменной полировки медных изделий в растворе сульфата аммония с добавлением серной кислоты. Эксперимент был разделен на два этапа. Сначала образцы обрабатывались в течение 600 секунд каждый для снятия температурных характеристик, при этом наблюдалась сильная корреляция между током нагрузки и температуры электролита. Зависимость тока от температуры электролита показала четыре разных режима обработки. Один из режимов показал наилучшие результаты. Во время второй серии эксперимента проводилась последовательная обработка объектов от 30 до 600 секунд. В результате проведенных исследований были получены оптимальные режимы (C) Mihal O.V., Moroz O.V., Starovoytov R.I., Buriak I.V., 2018 
полировки медных объектов.

КЛЮЧЕВЫЕ СЛОВА: электролитно-плазменное полирование, металлообработка, рельеф поверхности; модификация поверхности; температура электролита

Мідь є відомим матеріалом 3 широким спектром використання. Вироби 3 міді завдяки високій електропровідності незамінні в електротехніці, а висока теплопровідність зробила мідь найкращим матеріалом для ефективних теплообмінників та інших елементів конструкцій в хімічній, фармацевтичній, харчовій промисловості. При цьому мідь є пластичним металом, що порівняно легко оброблюється. Але для деяких виробів необхідною вимогою $є$ висока якість поверхні міді [1]. Зазвичай мала шорсткість поверхні забезпечується поліруванням, але для такої операції висока пластичність матеріалу є швидше перешкодою. При механічному поліруванні міді відбувається проникнення частинок абразиву в поверхню, що оброблюється [2], при цьому порушуються експлуатаційні характеристики виробу. Одним з методів отримання якісної поверхні 3 заданою шорсткістю є метод електролітно-плазмової обробки $[3,4]$. Незважаючи на те, що цей метод є відомим досить давно, він залишається актуальним і сьогодні все більше застосовується для фінішної обробки поверхні металів і сплавів [5-8]. Цьому способу обробки притаманне використання нетоксичних електролітів, що робить його привабливим для застосування при обробці виробів для фармацевтичної та харчової промисловості.

Мета роботи - оптимізація режиму обробки міді в процесі електролітно-плазмового полірування.

ЕКСПЕРИМЕНТ ТА ЕКСПЕРИМЕНТАЛЬНІ РЕЗУЛЬТАТИ

Дослідження динаміки процесу електролітно-плазмового полірування проводилися на установці, що зібрана за класичним компонуванням (рис. 1).

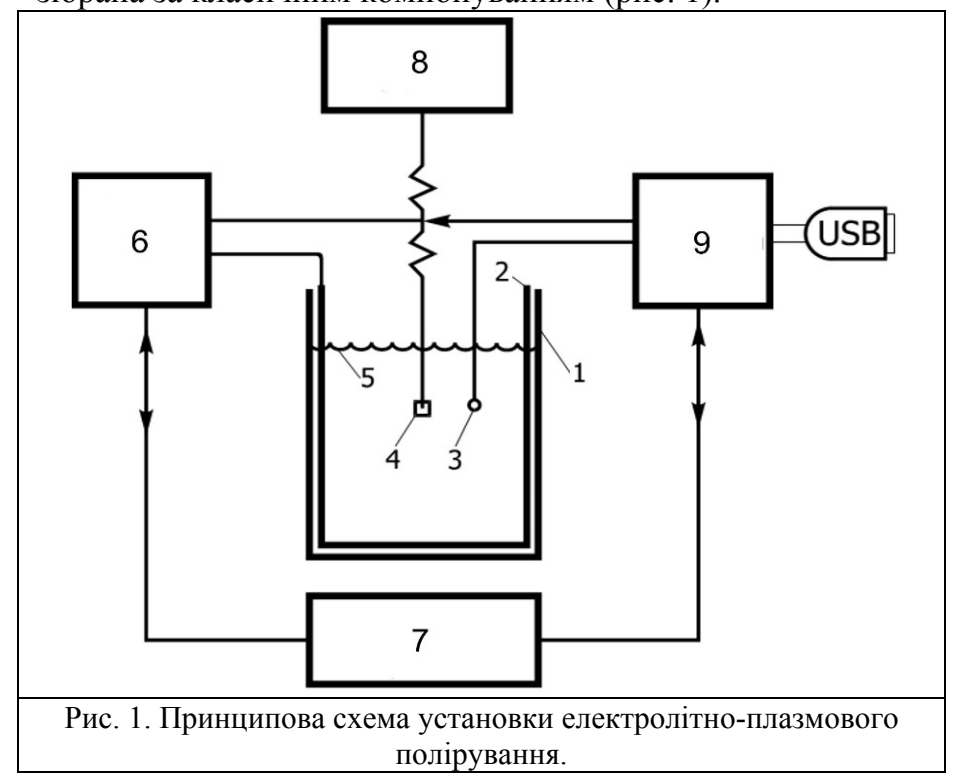

Установка складається 3 робочої камери об'ємом $\quad 0.6 \mathrm{~m}^{3}(1) ; \quad$ катода (2), датчика температури електроліту (3); утримувача об'єктів (4); електроліту (5); джерела живлення (6); системи управління (7); пристрою занурення (8); системи збирання і передачі даних (9). Катод виготовлений із нержавіючої сталі AISI 304 і покриває всю внутрішню поверхню вертикальних стінок бака. Його площа становить $0.3 \mathrm{~m}^{2}$. Джерелом живлення постійного струму $є$ трансформаторна трифазна система, зібрана за схемою Ларіонова 3 керованим мостом [9]. Джерело живлення забезпечує різницю потенціалів у 280 В і максимальний струм 120 А. Його вихідний опір становить 0.18 Ом. В установці передбачено блокування живлення за струмом, на рівні 100 А. Пристрій переміщення забезпечує занурення об'єкта в електроліт на задану оператором глибину 3 постійною швидкістю

$5 \mathrm{~mm} / \mathrm{c}$. Точність позиціонування - не гірше 1 мм. Система збирання та обробки даних вимірює струм навантаження, напругу джерела живлення, температуру електроліту. Збирання и передача даних проводяться зі швидкістю 20 вимірювань в секунду. Система забезпечує обмін даними між установкою та керуючим комп'ютером. Відносна похибка вимірювань за струмом і напругою не перевищує $0.5 \%$, за температурою $1 \%$. Система управління аналізує інформацію з системи збирання та обробки даних, отримує від комп'ютера команди керування процесом і забезпечує роботу всієї установки відповідно до заданої програми.

Як об'єкти дослідження використовувалися зразки розміром $75 \times 25 \times 2 \mathrm{mм}^{3}$, які були виготовлені 3 листової електротехнічної міді марки М2. Розмір зразків був обраний з міркувань мінімізації крайових ефектів на стан поверхні при електролітно-плазмовій обробці. Поверхня об'єктів містила сліди природної патини, незначні механічні пошкодження, які утворилися під час транспортування та зберігання мідних листів. Розподіл ушкоджень, їх характер і присутність забруднень на поверхні були рівномірними, отже, попередній стан поверхні об'єктів перед електролітно-плазмового обробкою можна вважати ідентичним. Перед зануренням в електроліт об'єкти не піддавалися попередній обробці. У всіх експериментах зразки занурювалися на глибину 25 мм.

Електролітом в експериментах був водний розчин сульфату амонію $з$ додаванням сірчаної кислоти. Вміст сульфату амонію в першому розчині становив $4 \%$, сірчаної кислоти $1 \%$. У другому розчині концентрація компонентів становила $3 \%$ і $0.5 \%$ відповідно. Концентрації компонентів указані в масових відсотках. За попередніми експериментами, в яких варіювалися концентрації компонентів, були визначені найбільш оптимальні з точки зору процесу електролітно-плазмового полірування параметри розчину. Таким виявився перший розчин. 
У процесі електролітно-плазмової обробки відбувається нагрівання електроліту. У зв'язку 3 цим дослідження проводилися в кілька серій, у кожній серії використовували п'ять об'єктів. Початкова температура електроліту в кожній серії відповідала кімнатній, у нашому випадку це було $22{ }^{\circ} \mathrm{C}$. Експеримент у кожній серії відбувався так: перший об'єкт закріплювали на тримачі та занурювали в електроліт, після чого починали процес полірування, що тривав 600 с. Протягом усього процесу проводився безперервний запис струму навантаження, напруги на об'єкті та температури електроліту, по закінченню встановленого терміну обробки відключали напругу, і об'єкт автоматично виймали з електроліту. Після заміни об'єкту процес повторювали. Таким чином, кожен наступний зразок у серії занурювався в електроліт за більшої температури. Це надало можливість дослідити залежність струму навантаження від початкової температури електроліту. Характерні залежності зміни температури електроліту від часу для однієї серії з п'яти зразків представлені на рис. 2, електролітом був перший розчин.

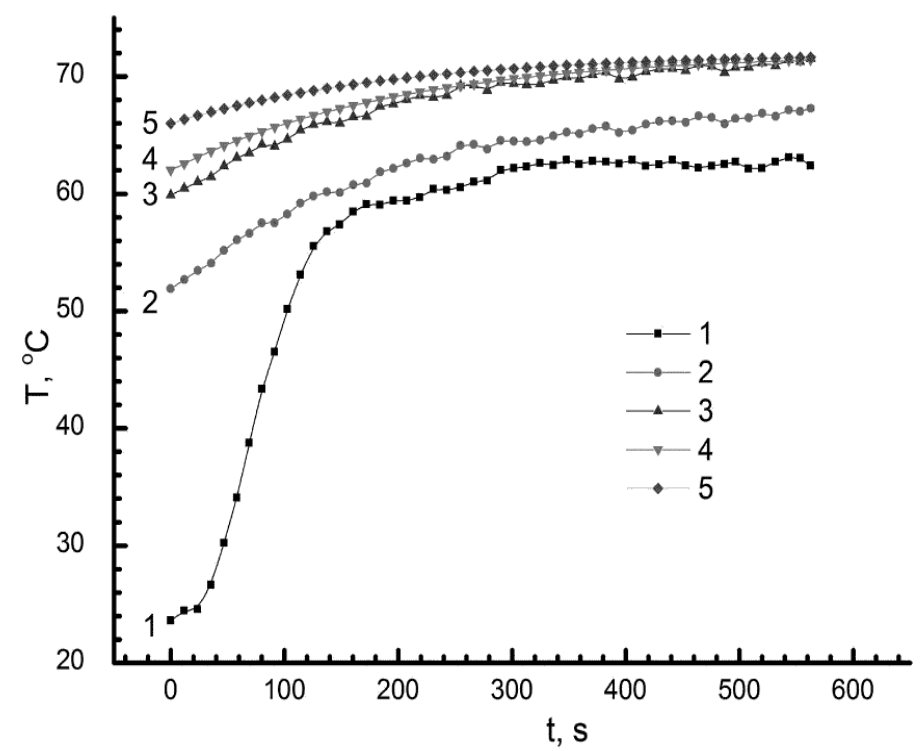

Рис. 2. Характерні залежності зміни температури електроліту від часу для однієї серії з п'яти об'єктів.

Отримані дані свідчать, що температура електроліту безперервно підвищується, наближаючись до деякого максимального значення. У всіх випадках характер зміни температури був однаковим. Максимальна температура електроліту для наших умов становила $(72 \pm 1){ }^{\circ} \mathrm{C}$.

Завдяки конструкції джерела живлення, протягом всього часу обробки напруга на зразку була однаковою i становила 280 В. Струм навантаження при цьому змінювався за складним законом. Залежність струму навантаження від часу для першого зразка в серії представлена на рис. 3.

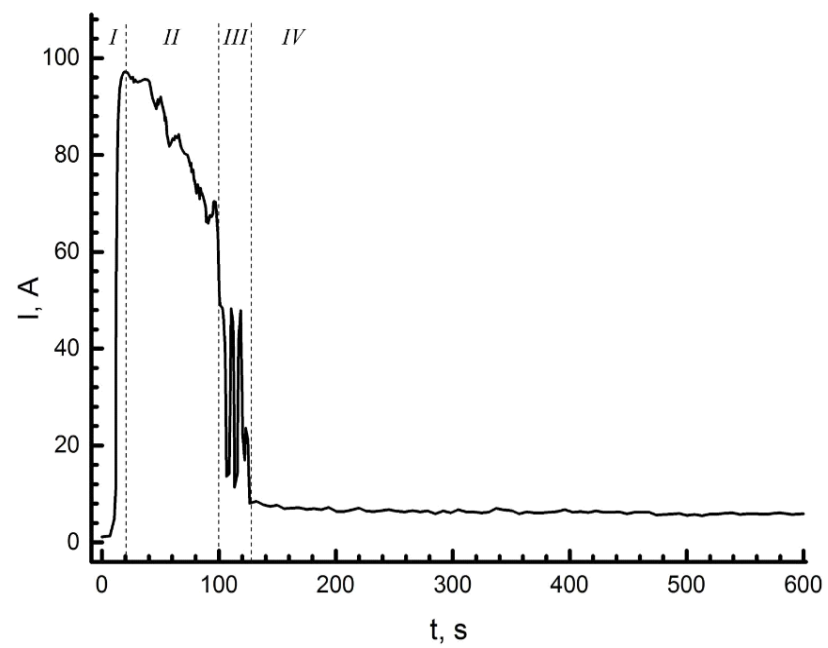

Рис. 3. Залежність струму навантаження від часу обробки для об'єкта, який занурюється в електроліт при початковій температурі $\mathrm{T}_{\mathrm{s}} 22^{\circ} \mathrm{C}$.

На залежності струму від часу можна виділити кілька областей, на рис. 3 вони позначені римськими цифрами. Так область I відповідає зануренню об'єкта в електроліт. У другій області відбувається нагрівання зразка в електроліті. При цьому спостерігаємо виділення газу на поверхні зразка, що свідчить про відбування процесу електролізу. 3 нагріванням об'єкту та електроліту зменшується струм. У третій області відбувається 
перехід від електрохімічної обробки до електролітно-плазмової. У цей період температура зразка і електроліта не забезпечують формування стабільної парогазової оболонки, це підтверджується сильними коливаннями струму. У четвертій області температура об'єкта підвищується то настільки, що навкруги нього формується стабільна парогазова оболонка. Протікання струму в ланцюзі забезпечується пробоєм парогазової оболонки 3 формуванням газового розряду постійного струму. Анодом газового розряду $є$ виріб, що оброблюється, а катодом - поверхня рідини. Робочим тілом (газом) для розряду є парогазова оболонка, що відокремлює електроліт від поверхні об'єкта. 3 підвищенням початкової температури електроліту час існування другої і третьої області скорочуються, при цьому максимальні струми для кожної області зменшуються (рис. 4).

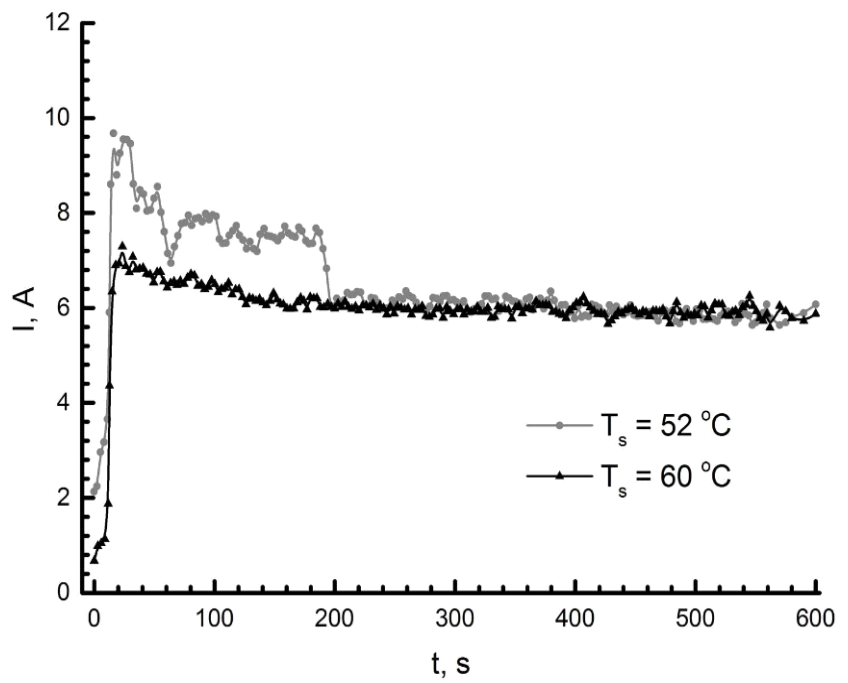

Рис. 4. Залежності струму навантаження від часу обробки для об'єктів, який занурюється в електроліт при початкових температурах $\mathrm{T}_{\mathrm{s}} 52^{\circ} \mathrm{C} \mathrm{i} 60^{\circ} \mathrm{C}$.

На рис. 4 представлені залежності струму навантаження від часу для випадків, коли зразок занурювався в електроліт 3 початковою температурою $\mathrm{T}_{\mathrm{s}} 52 \mathrm{i} 60{ }^{\circ} \mathrm{C}$. Це відповідає другому і третьому об'єкту в серії. Залежності для четвертого і п'ятого об'єктів не показані, оскільки вони майже збігаються з залежністю для третього об'єкта та тільки захаращують рисунок. Простежується кореляція між струмом навантаження та температурою електроліту. Як видно з кореляційного налізу, починаючи $355^{\circ} \mathrm{C}$, взаємний зв'язок між струмом навантаження і температурою електроліту $є$ сильним і має зворотний характер. Це справедливо для всіх експериментів усіх серій з мідними зразками в електроліті (склад якого наводили вище).

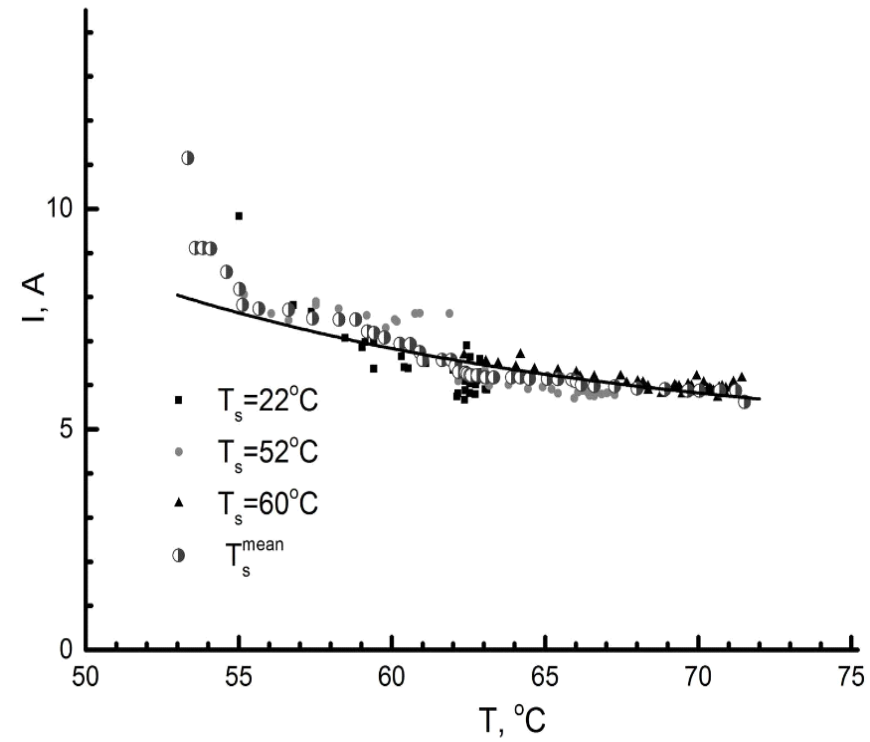

Рис. 5. Залежності струму навантаження від температури електроліту для випадків занурення об'єктів в електроліт з початковими температурами $\mathrm{T}_{\mathrm{s}} 22,52 \mathrm{i} 60^{\circ} \mathrm{C}$,

$\mathrm{T}_{\mathrm{s}}^{\text {mean }}$ - усереднене значення за всіма серіями, суцільна лінія - апроксимуюча крива.

Залежності струму навантаження від температури електроліту наведені на рис. 5. На цьому рисунку вказані значення для струму навантаження для випадків занурення об'єктів в електроліт 3 початковими температурами 22,52 i $60{ }^{\circ} \mathrm{C}$, усереднене значення за всіма серіями $\left(\mathrm{T}_{\mathrm{s}}^{\text {mean }}\right)$ та апроксимуюча крива.

Експерименти свідчать, що рельєф поверхні після обробки зразків протягом 600 с не залежить від 
початкової температури електроліту. Для визначення оптимальних умов полірування виробів із міді проводилась обробка об'єктів із послідовним збільшенням тривалості на 30 с. Початкова температура розчину становила $60{ }^{\circ} \mathrm{C}$. Фотографії ділянки поверхні представлені на рис. 6.

Після перших 30 с обробки (рис. 6а) поверхня зразка не відрізнялася від вихідної. При цьому процес обробки містить в собі дві області, позначені на рис. 3 як I і II. Це області, у яких відбувається прогрівання зразка, і тільки починає формуватися парогазова оболонка. При обробці поверхні зразка понад 60 с (рис. 6b) помітне притуплення гострих країв на поверхні, патина залишається майже не пошкодженою. За 60 с другого циклу процес обробки проходить вже три області, що позначені на рис. 3 як I, II і III.

Електроліт достатньо прогрівається, щоб періодично формувалася суцільна парогазова оболонка та виникали умови газового розряду в ній (що побічно підтверджується сильними коливаннями струму). У третьому випадку, коли зразок оброблявся 90 с (рис. 6с), патина зникла повністю, поверхня об'єкта набула металевого блиску. На графіку залежності струму від тривалості обробки наявні всі області, зазначені на рис. 3.
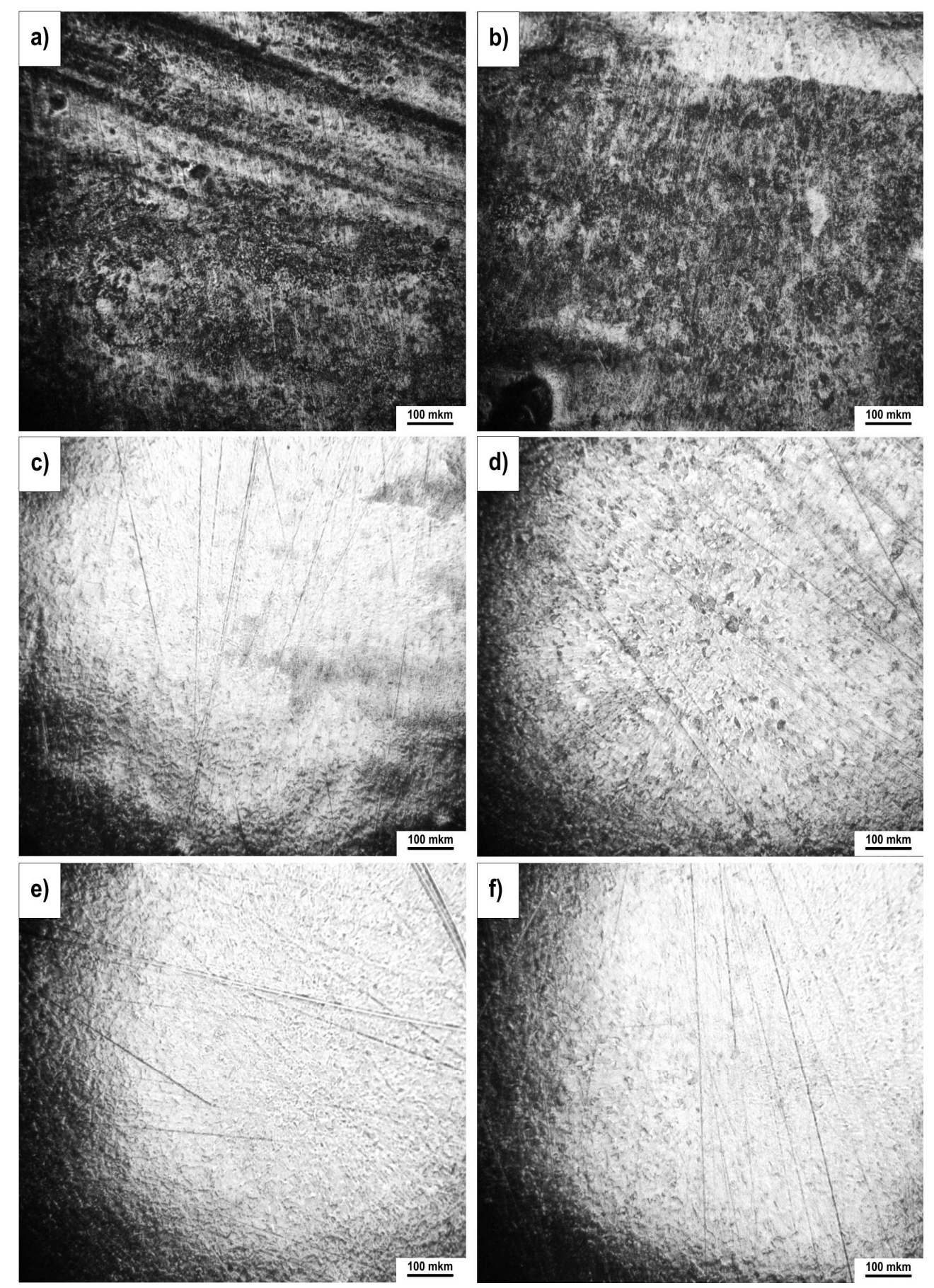

Рис. 6. Мікроструктура ділянок поверхні мідного об'єкта при послідовній обробці, тривалість кожної обробки 30 с, початкова температура електроліту $\mathrm{T}_{\mathrm{s}}$ становила $60{ }^{\circ} \mathrm{C}$. 
Обробка протягом 120 с призводить до видалення приповерхневого шару і виявлення границь зерен матеріалу (рис. 6d). Обробка протягом 150 с призвела до згладжування країв зерен і відновлення блиску зразка (рис. 6е). Подальше збільшення часу обробки не привело до вагомих покращень якості поверхні (рис. 6f).

Таким чином, можна зробити висновок, що полірування об'єктів відбувалася за умов, які реалізуються в області IV (рис. 3).

\section{ВИСНОВКИ}

1. Мідні вироби можуть бути відполіровані в електроліті, що містить 4 \% сульфату амонію та $1 \%$ сірчаної кислоти (масові \%).

2. Зменшення концентрації зазначених компонентів нижче 3 \% і 0.5 \% відповідно не є доцільним.

3. Процес полірування є можливим тільки за умови формування суцільної стійкою парогазової оболонки навколо виробу.

4. Основні процеси при полірування відбуваються на поверхні виробу в плазмі газового розряду.

5. Тривалість обробки після переходу від електролізної стадії до стадії газового розряду в парогазовій оболонці може становити 60-90 с, при цьому основні параметри шорсткості поверхні $\mathrm{R}_{\mathrm{a}} \mathrm{i} \mathrm{R}_{\mathrm{z}}$ [10] зменшуються в середньому в 3-5 разів порівняно з початковими значеннями.

Спираючись на отримані результати, було здійснено полірування мідних виробів, які є елементами ректифікаційної колони для виробництва ефірних масел. Зовнішній вигляд виробів до і після обробки представлений на рис. 7.

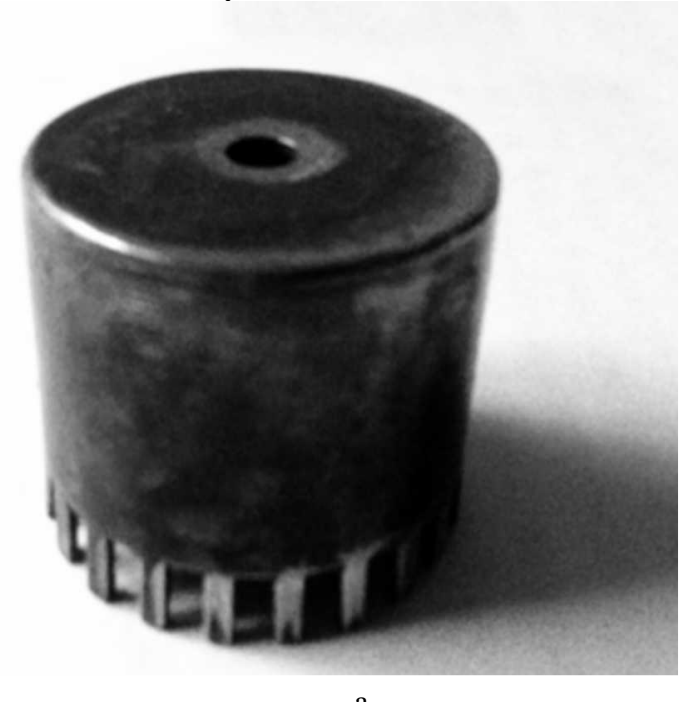

a

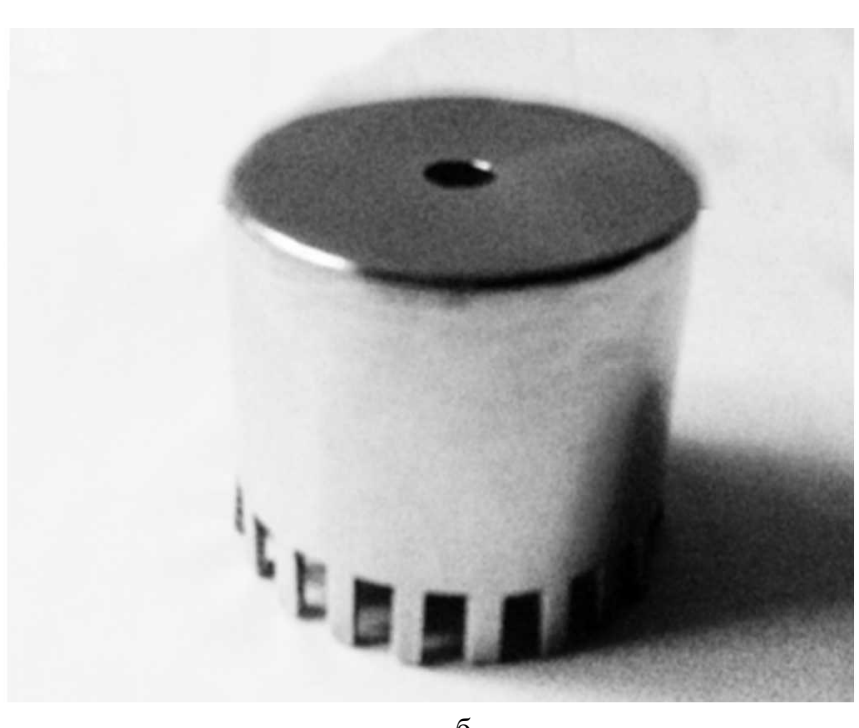

6

Рис. 7. Елементи ректифікаційної колони

а) - до електролітно-плазмового обробки і б) - після електролітно-плазмового обробки

Спочатку поверхню виробів містила оксидні та інші відкладення, поверхня перед поліруванням попередньо не обробляють. Повний час електролітно-плазмового полірування цих виробів в електроліті, який мав склад: 4\% сульфату амонію і 1\% сірчаної кислоти, становило 150 с, початкова температура електроліту $60^{\circ} \mathrm{C}$. Електролітно-плазмова полірування цих виробів показала високий результат.

\section{СПИСОК ЛІТЕРАТУРИ}

1. Sung Chul Cha, Ali Erdemir. Coating Technology for Vehicle Applications. - Cham: Springer International Publishing, 2015. $240 \mathrm{p}$.

2. Garber M.I. Dekorativnoeshlifovanie i polirovanie, 2-e, dop. i pererabot. ed [Decorative grinding and polishing]. - Moskva: Mashinostroyenie, 1964. - P.192. (In Russian)

3. Yerokhin A.L., Nie X., Leyland A., Matthewsand A., Dowey S.J. Plasma electrolysis for surface engineering // Surface and Coatings Technology. - 1999. - No. 122. - P. 73-93.

4. Pogrebniak A.D., Tiurin Iu.N., Boiko A.G., Zhadkevich M.L., Kalyshkanovand M.K., Ruzimov Sh.M., Elektrolitnoplazmennaiaobrabotka i naneseniepokrytii na metally i splavy [Electrolyte-plasma processing and coating on metals and alloys] // Uspekhifiz. Met. - 2005. - Vol. 6. - P. 273-344.

5. Gupta P., Tenhundfeld G., Daigleand E.O., Ryabkov D., Electrolyticplasmatechnology: Science and engineering - Anoverview // Surface\&Coatings Technology. - 2007. - No. 201. - P. 8746-8760.

6. Parfenov E.V., Yerokhin A., Nevyantseva R.R., Gorbatkov M.V., Liangand C.-J., Matthews A., Towards Smart Electrolytic Plasma Technologies: An Overview of Methodological Approaches to Process Modelling // Surface\&Coatings Technology. 2015.

7. Ushomirskaia L.A., Gerasimov A.S. Tekhnologicheskie vozmozhnjsti primeneniia struinogo techeniia elektrolita pri elektrolitno-plazmennom polirovanii [Technological possibilities of application of a jet stream of electrolyte at electrolytic 
plasma polishing] // Metalloobrabotka. - 2015. - No. 4. - P. 25-30.

8. Nestler K., Böttger-Hiller F., Adamitzki W., Glowa G., Zeidlerand H., Schubert A. Plasma Electrolytic Polishing - an Overview of Applied Technologies and Current Challenges to Extend the Polishable Material Range // Procedia CIRP. - 2016. - No. 42. - P. $503-507$.

9. Rashid M. H. Power electronics handbook, Elseviered., Ed., Oxford, UK: Elsevier, 2011. - 1409 p.

10. BS EN ISO 4287:2000, Geometrical product specification (GPS). Surface texture. Profile method. Terms, definitions and surface texture parameters. 